\title{
POIMANJE I TEMELJNA ZEMLJOPISNA OBILJEŽJA PODGORJA
}

\author{
Mladen Klemenčić \\ Leksikografski zavod Miroslav Krleža \\ Frankopanska 26 \\ HR 10000 Zagreb \\ mladen.klemencic@lzmk.hr
}

\author{
UDK: 911.3(497.5 Podgorje) \\ 913(497.5) \\ Pregledni članak \\ Ur.: 2017-01-24
}

U izlaganju se raspravlja prostorni obuhvat i poimanje Podgorja kao specifične hrvatske regije. Po mnogim svojim obilježjima Podgorje je netipičan dio hrvatskog uzmorskog pojasa, sa specifičnim identitetskim obilježjima. Već i sam naziv upućuje na planinu, a ne na more kao ishodište. Oko točne definicije područja koje Podgorje obuhvaća, u literaturi postoje različita gledišta. Podgorska uzmorska mjesta svojim izgledom odudaraju od uobičajenoga izgleda naših primorskih gradića, dok ruralna naselja imaju fizionomiju sela dinarskoga planinskog pojasa. Nadalje, iznose se glavna obilježja naseljenosti područja. Bez grada Senja, ali čak i s njime, to je najrjeđe naseljeni dio Hrvatske. U prometnom pogledu, ključna je bila u 1950-im godinama izgradnja Jadranske magistrale, koja je uzdužno povezala cijelo Podgorje.

Ključne riječi: Podgorje, zemljopisna obilježja

\section{Uvod}

Kada su raspisane prijave za znanstveni skup posvećen Podgorju, u pratećem obrazloženju nije bilo posebne napomene o značenju toponima Podgorje. Smatralo se da je pojam razumljiv sam po sebi, uzimalo ga se zdravo za gotovo. Značenje i sadržaj tog regionalnog toponima odnosno horonima. ${ }^{1}$ Podgorje nitko nije dovodio u pitanje pa nije to namjera ni ovoga podneska. Slažemo se načelno da je Podgorje jedan od onih zemljopisnih pojmova na koje smo naviknuti i o čijem značenju ne treba svaki puta iznova raspravljati. Ipak, uvidom u dosadašnju stručnu literaturu ustanovili smo da nije na odmet raspraviti što i kako se o Podgorju dosad pisalo, koje se područje točno Podgorjem smatralo

\footnotetext{
${ }^{1}$ Horonim je specijalistički kartografski naziv za toponim koji označava naziv za regiju.
} 
i kako se podgorsko područje razvrstavalo u radovima koji se bave tematikom regionalne podjele.

Kada se govori o nekome kraju, zemljopisnoj, povijesnoj ili povijesnozemljopisnoj regiji, nastoji ga se između ostaloga i omeđiti ili preciznije odrediti pripadajuće mu područje te izdvojiti obilježja po kojima se taj kraj razlikuje od sebi susjednih krajeva ili regija, tj. obilježja po kojima se taj kraj prepoznaje $\mathrm{u}$ širem makroregionalnom i subnacionalnom kontekstu pa i cjelokupnom nacionalnome spektru većih i manjih regionalnih sastavnica. Rasprava o postojanju i teritorijalnome opsegu neke regije zapravo je pokušaj definiranja identiteta neke regije, pokušaj isticanja onih obilježja po kojima je ta regija jedinstvena i neponovljiva. Hrvatska je zemlja bogato raščlanjena regijama. One su uvjetovane različitim čimbenicima, a razlikuju se i po veličini. Nerijetko se regije i preklapaju, unutar većih regija postoje manja područja koja se po svojim obilježjima mogu smatrati i zasebnim regijama. Stoga jedno te isto područje, ovisno o kontekstu i razini promatranja, može biti i regija po sebi a istodobno i dio neke veće, prostorno nadređene cjeline.

Jasnijem prepoznavanju regije pridonosi i njezin naziv. Po tome se tradicionalne regije, one što se u svakodnevnom govoru spominju bez imalo zadrške, kao da su već samim nazivom dovoljno jasno određene, razlikuju od regija koje se pojavljuju u stručnoj literaturi. Primjeri takvih, općeprihvaćenih naziva u Hrvatskoj jesu nazivi velikih povijesnih pokrajina Dalmacija, Slavonija ili Istra, a od prostorno manjih regija spomenuti ćemo, primjerice, Liku ili Žumberak. Spomenute horonime koristi se u svakodnevnoj komunikaciji bez ikakva sustezanja iako detaljniji uvid za svakog od njih govori da su njihove međe vremenski bile promjenljive, stoga dva sugovornika govoreći o istoj regiji ne misle nužno na do u detalj isto područje. U stručnoj, a napose geografskoj literaturi, regije se javljaju ponajprije u kontekstu tzv. regionalizacija, sustavnih raščlambi prostora, organiziranih najčešće u nekoliko razina, prema nekom ili nekoliko više ili manje egzaktnih kriterija (fizičkogeografski, demografski, prometni, gospodarski, etnografski). Obično se govori o osnovne dvije vrste regionalizacija. ${ }^{2}$ Jedna se naziva fizionomskom ili uvjetno homogenom $i$ zasniva se na načelu geografske homogenosti, a druga nodalno funkcionalnom ili gravitacijskom, a zasniva se na prepoznavanju područja utjecaja pojedinih naselja. Nazivi tradicionalnih zemljopisnih regija koriste se u prvoj vrsti regionalizacija, no obično uz neke prilagodbe i dodatke, pa se može reći da su ponajprije kabinetske naravi, gdjekad i bez potvrde u mjesnom topografskom

${ }^{2}$ V. ROGIĆ, 1973, 14. 
inventaru. Kao primjere navodimo nekoliko slučajno odabranih: Sjeverno Hrvatsko primorje, Kvarnerski primorsko-otočni prostor ili Vinodolsko flišno zaobalje. Autori regionalizacija prilagođuju takve nazive ponajprije u okviru sustava kojega postavljaju za Hrvatsku u cjelini, vodeći računa o hijerarhiji tako da nazivi manjih regije na nižim razinama budu usklađene s nazivima onih na višim razinama raščlambe.

Uvodno iznesene napomene vrijede i za dio Hrvatske nazvan Podgorjem. Riječ je o toponimu koji se na prvi spomen prepoznaje bez imalo dvojbe i bez potrebe konzultiranja izvora ili literature. Najkraća definicija Podgorja bila bi da je to dio obale na primorskoj strani Velebita, oblikom izduljen duž morske crte, dok je po širini, prema unutrašnjosti, to razmjerno uzak pojas, stisnut između obalne crte i glavnog velebitskog planinskog bïla. Gledano od sjevera prema jugu, počinje negdje oko Senja, a završava u podnožju južnoga Velebita. Gledano u širem kontekstu, riječ je o dijelu hrvatskoga priobalja ili primorja. Za potpuniji uvid u definiciju područja ali i sam naziv - jer Podgorje ipak nije jedini korišteni naziv za to područje - slijedi pregled izabranih naslova iz geografske stručne kao i srodne općezemljopisne literature.

\section{Podgorje u literaturi}

Najstariji konzultirani izvor jest pionirska zemljopisna sinteza s početka 20. stoljeća. ${ }^{3}$ Autor spominje Podgorje opisujući Velebit. Ključna rečenica pomalo je dvosmislena pa ju navodimo u cijelosti: "Jugo-zapadna strana Velebita poznata je kao 'Primorski Kras', što se pod imenom Podgorje stere bivšom otočkom i ličkom pukovnijom." Ne navodi se izravno, no iz konteksta je vidljivo da opisujući Podgorje Hirc misli na dio obale "od Senja do Dalmacije".

Kao vrijedni izvori pokazala su se i dva reprezentativna planinarska vodiča po Velebitu. Oba priručnika obiljem podataka i informacija koje donose na stručnoj razini uvelike nadmašuju uobičajene domete putnih vodiča po nekom kraju, stoga ih se može smatrati dragocjenim općezemljopisnim i povijesnokulturnim vrelom svakovrsnih informacija o širem velebitskom području. U starijem vodiču ${ }^{4}$ navodi se pojam Podgorje kao središnji dio primorske strane Velebita. Niži pojas uz more naziva se Primorjem, a viši koji seže do glavnog planinskog hrpta jest Nadgorje. Podgorje, prema Poljaku, zaprema prostor na nadmorskoj visini 3001000 m, dok je Primorje naziv za pojas između morske obale i približno $300 \mathrm{~m}$

${ }^{3}$ D. HIRC, 1905, 448.

${ }^{4}$ J. POLJAK, 1929, 45. 
nadmorske visine. Prema toj raščlambi primorje je naseljeniji dio, dok u Podgorju "ima malo stalnih naselja". Kada se govori o stanovnicima, Podgorcima se osim onih što nastanjuju Podgorje nazivaju i oni koji žive u ostala dva pojasa.

Drugi spomenuti vodič ${ }^{5}$ u dijelu gdje se opisuje reljef planine, navodi da njezina primorska strana "ima dvije jasno izražene uzdužne terase koje se poput golemih stepenica pružaju podnožjem i sredinom planine. Ona na podnožju, u blizini mora, poznata je pod imenom Podgorje". Štoviše, Podgorje je i preciznije opisano pa se kaže da ta podgorska terasa "počinje kod Jurjeva na visini od oko $60 \mathrm{~m}$ ", dalje uz blagi porast visine najveću širinu od oko 3 $\mathrm{km}$ dostiže kod Jablanca, a onda se u nastavku prema jugu ponovno suzuje i naposljetku završava u sjevernodalmatinskoj zaravni oko kanjona rijeke Zrmanje. Onu drugu terasu, koja se nalazi na visini od 800-900 m, autor naziva više tehničkim terminom "žljebaste udoline", iznad koje kao još viši visinski pojas dolazi "visokoplaninska zona".

Kronološkim redom između dva citirana planinarska izvora jest opsežni rad geografa Rogića, objavljen u dva nastavka u časopisu Geografski glasnik ${ }^{6}$, a potom i integralno kao monografija niza Radovi geografskog odjela (instituta). Rogićev rad Velebitska primorska padina, iako naslovom upućuje na Velebit, zapravo je geografska monografija Podgorja. Donosi detaljnu geografsku analizu područja, no sam naziv Podgorje izrijekom nije u prvom planu.

U još uvijek najopsežnijem geografskom stručnom prikazu Hrvatske, monografiji u šest svezaka, Podgorje je opisano u petoj knjizi ${ }^{7}$ koja se odnosi na Sjeverno hrvatsko primorje. Pod nazivom Velebitsko podgorje područje je definirano kao priobalni pojas "od Ledenica pa do Zrmanje", odnosno prema tadašnjoj upravnoj podjeli kao "područje općine Senj i primorskog dijela općine Gospić" koje "čini geografski izdvojenu subregionalnu cjelinu sjevernog velebitskog podgorja". Valja upozoriti da navedena definicija nije točna: naime, ako se Podgorje uzima od Ledenica, odnosno od uvale Žrnovnice koja je Ledenicama najbliža točka na obali, onda je ono osim navedenih upravnih jedinica tada obuhvaćalo i dio tadašnje općine Crikvenica.

Veliki atlas Hrvatske ${ }^{8}$ ima pojam Podvelebitsko primorje, a ono se "pruža od Ledenica na sjeveru do Zrmanje na jugu" te je opisano kao "relativno visok

${ }^{5}$ Ž. POLJAK i suradnici, 1969, 16.

${ }^{6}$ V. ROGIĆ, 1957; V. ROGIĆ, 1958.

${ }^{7}$ Geografija SR Hrvatske, 1975, 125-136.

${ }^{8}$ Veliki atlas Hrvatske, 2002, 294-295. 
kraj prostranih ogoljelih padina vapnenačkog sastava", i "najslabije je naseljen dio hrvatskog primorja". Među malobrojnim naseljima ističe se značenje Senja.

Najnoviji konzultirani izvor jest udžbenička monografija geografa Magaša. ${ }^{9}$ Prema Magaševoj uvjetno-homogenoj regionalizaciji Hrvatske područje našeg zanimanja prepoznato je kao zasebna jedinica pod nazivom Kvarnerska velebitska primorska padina ili alternativno Sjeverno velebitsko podgorje i to na najnižoj, četvrtoj razini prostorne raščlambe. Nadređene regijske cjeline, u okviru kojih se nalazi, jesu Kvarnersko primorje, Kvarnerski primorsko-otočni prostor, Sjeverno hrvatsko primorje i Hrvatsko primorje. Posljednja navedena cjelina jedna je od tri velike makroregije što ih Hrvatska obuhvaća. Manji, južni dio područja našeg zanimanja pod nazivom Južno velebitsko podgorje razvrstan je kao cjelina u okviru Srednjehrvatskog priobalja odnosno Srednjohrvatskog priobalja i otoka i Srednjeg hrvatskog primorja kao dijela Hrvatskoga primorja. Sjeverno velebitsko podgorje Magaš je definirao kao područje "južno od Ledenica pa sve do međe s prostorom Karlobaga (Ličko velebitsko podgorje)". Južno velebitsko podgorje definirao je kao "jugoistočni dio primorsko-podgorskog pojasa", a iz teksta je vidljivo da su u taj pojas ubrojeni i karlobaški i starigradski dio.

Navedenim primjerima treba dodati i dva enciklopedijska izvora, kao referente priručnike opće namjene. Hrvatska enciklopedija ${ }^{10} \mathrm{u}$ izdanju Leksikografskog zavoda Miroslav Krleža u 11. svesku (2009) ima Velebitsko podgorje s definicijom "područje u podnožju Velebita, između Senja i rijeke Zrmanje" a Opća i nacionalna enciklopedija ${ }^{11}$ u nakladi Pro leksisa i Večernjeg lista u posljednjem 20. svesku ima također pojam Velebitsko podgorje s istom definicijom.

Ako se iz navedenih definicija i regionalizacija pokuša izlučiti zajedničke elementa odnosno razlike, dolazi se do nekoliko zaključaka. Prvo, naziv kraja nije ustaljen. Naziv Podgorje javlja se i u inačici Velebitsko podgorje, a ostale korištene horonimske inačice su i Podvelebitsko primorje odnosno Velebitska primorska padina. Važno je pritom uočiti važnost Velebita koja se ogleda u činjenici da i sam pojam Podgorje bez velebitskog predmetka ili s njim naglašava važnost planine, iako se odnosi na kraj uz more. Drugo, nisu jednoznačno određene međe Podgorja. Ako se gleda po duljini, kao sjeveroistočna međa ili početak navode se Ledenice, Senj pa čak i Jurjevo (Sveti Juraj). Kao jugoistočnu među odnosno svršetak većina autora navodi donji tok rijeke Zrmanje, ali se kao

\footnotetext{
${ }^{9}$ D. MAGAŠ, 2013, 169.

${ }^{10}$ Hrvatska enciklopedija 11 (Tr-Ž), 2009, 314

${ }^{11}$ Opća i nacionalna enciklopedija XX (T1-Ž), 2007, 211.
} 
južna međa spominje i povijesna granica Dalmacije, koja na morsku obalu izbija u Svetoj Mariji Magdaleni (Svetoj Mandalini). Ako stara povijesna dalmatinska granica i ne označava južnu među Podgorja, ona svakako jest zanimljiva kao crta koja dijeli Podgorje na dvije podcjeline, sjevernu i južnu. Te dvije cjeline nisu toliko prirodno različite, no izduljenost Podgorja kao cjeline ipak upućuje na logičnu pretpostavku da se barem krajnji dijelovi tog pojasa po nekim obilježjima donekle razlikuju. Tome pridonosi i važeća upravna podjela prema kojoj je stara dalmatinska granica danas i granica dviju županija, Ličko-Senjske i Zadarske. Stoga nimalo ne čudi da je podjela Podgorja na sjeverni i južni dio primijećena i zabilježena baš i u najnovijoj geografskoj regionalizaciji, onoj Magaševoj. Gledano po širini, Podgorjem se smatra cijela primorska strana Velebita od glavnoga bïla do morske obale, ali je zabilježena i uža prostorna definicija prema kojoj je Podgorje samo donji dio te padine ili, najuže, samo središnji dio donjeg dijela velebitske padine tzv. podgorski prag kojime uglavnom ide trasa Jadranske magistrale.

Prema izvorima koji su uzeti u obzir može se zaključiti da je pojam Podgorja kao zasebne regije na sjevernom dijelu hrvatskog priobalja prepoznat, ali da oko točnoga prostornog obuhvata postoje razlike u gledanju. Razlike nisu samo u pružanju Podgorja prema jugu, nego i oko sjeverne međe regije, sve do dvojbe je li Senj kao najveće naselje dio same regije ili samo najbliže gradsko središte kojemu Podgorje gravitira. Kod te dvojbe, korisno je uzeti u obzir i iskustveno poznate nam lokalne običaje, odnosno poimanje lokalnoga stanovništva. Naime, u samome gradu Senju rijetko će se tko složiti da je Senj dio Podgorja. Za Senjane samo je po sebi razumljivo da je Podgorje dio priobalnog područja južnije od Senja.

Postojanje podgorskoga identiteta u pojedinih stanovnika područja ustanovili su i autori opsežnog istraživanja ${ }^{12}$ osjećaja regionalne pripadnosti koje je obuhvatilo, nažalost za nas, samo južni dio Podgorja. Zastupljenost podgorskog identiteta manja je od zastupljenosti ostalih anketom ponuđenih identiteta. Da bi se točnije utvrdio međuodnos podgorskog s drugim, nadređenim identitetima, poglavito dalmatinskim, autori su ustvrdili da bi bilo potrebno "izvršiti ciljano anketno istraživanje....s detaljnim skupom pitanja". Nama ne preostaje drugo nego zaključiti da bi jedino istovrsno istraživanje za područje sjevernoga Podgorja, uključujući i grad Senj, dalo i precizan odgovor na dvojbu o (ne)pripadnosti Senja podgorskoj regiji.

${ }^{12}$ L. MIROŠEVIĆ - B. VUKOSAV, 2010, 103-104. 


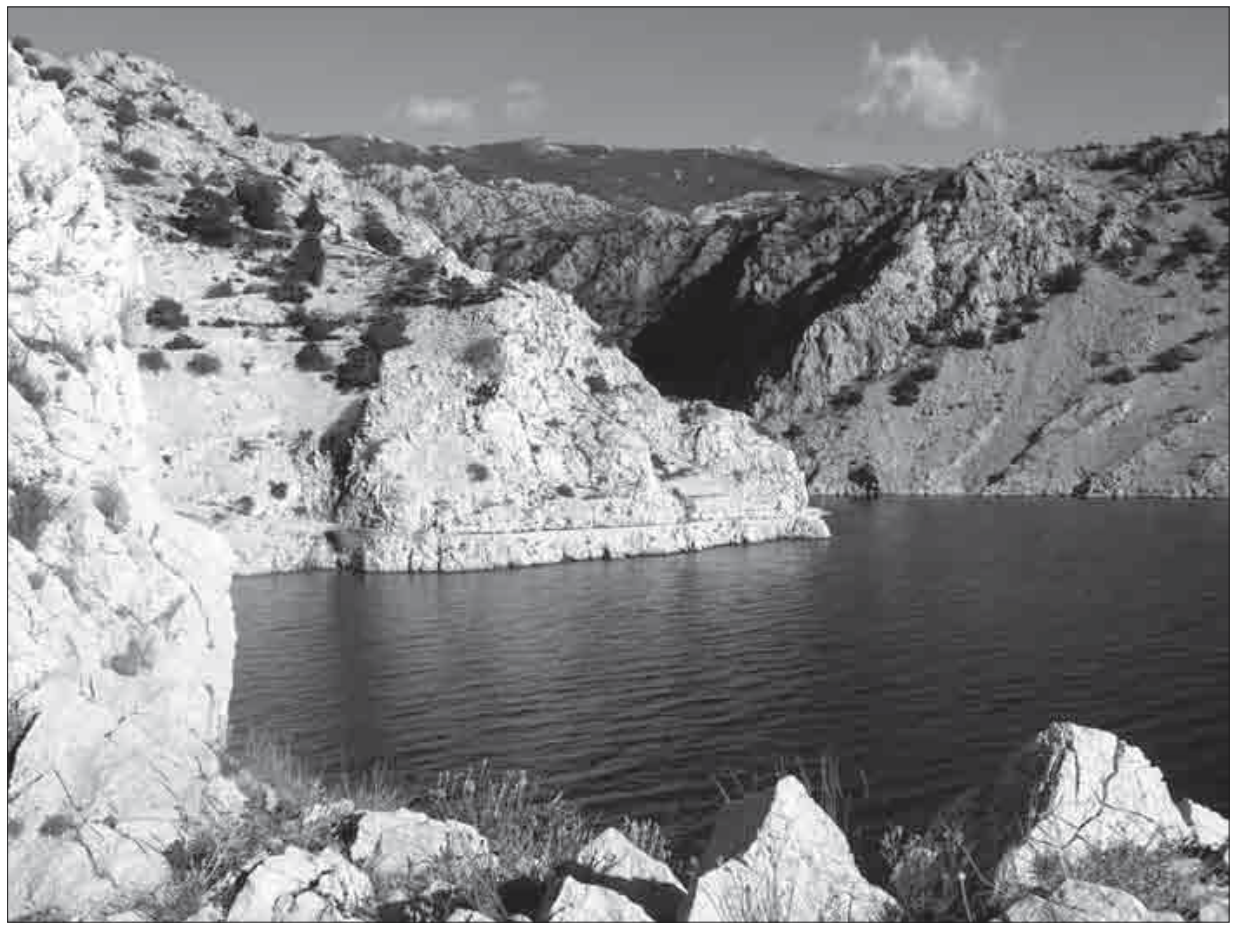

S1. 1. Uvala Zavratnica, foto: M. Klemenčić, 2009.

\section{Temeljna zemljopisna obilježja}

Bez obzira na ustanovljene razlike glede poimanja prostornog obuhvata regije, temeljne zemljopisne značajke Podgorja ipak je moguće sažeto iznijeti. One su bitne za poimanje Podgorja kao specifičnog dijela hrvatskoga priobalnog pojasa. Riječ je o području stiješnjenom između velebitskih vrhova i morske obale. Padine su raščlanjene suhim jarugama, nerijetko i kanjonskoga izgleda, koje prema moru završavaju strmcima ili potopljenim dragama. Najpoznatija takva draga jest Zavratnica kod Jablanca. Obala je velikim dijelom prilično nepristupačna, no mjestimice ima dobro zaklonjenih uvala, a uz njih su redovito vezana i postojeća naselja i luke. S obzirom na izduženost u smjeru sjeverozapad-jugoistok, smjeru osnovnog pružanja glavnog velebitskog bila i obalne crte, Podgorje nema cijelom duljinom potpuno jednaku širinu i poprečni profil, no na cijeloj svojoj duljini nema znatnijih ravničarskih dijelova. Donekle se tek izdvaja nešto širi nizinski pojas između obale i Velebita kod StarigradaPaklenice i Selina. 
Godišnje padne dosta oborine, no osnovno obilježje klime je sušnost, koja je posljedica vapnenačkog sastava, osojne ekspozicije te ponajprije bure. Vlagu što ju donesu oborine, pometu silni naleti bure koja i ljeti, a osobito zimi, puše orkanskom jačinom. Usporedba raspodjele vjetrova duž naše obale pokazuje da je čestina bure u Senju višestruko veća nego u drugim primorskim gradovima. ${ }^{13}$ Prevladavaju topla ljeta i suhe, a hladne zime sa čestim snižavanjem temperature zbog bure. Osim bure, kao prevladavajućeg vjetra, obilježje Podgorja jest $\mathrm{i}$ znatno manji udjel maestrala, inače redovitog vjetra na većem dijelu obale te natprosječna zastupljenost dana bez vjetra, potpunih bonaca ili tišina. Zbog toga je Senj, osim što prednjači u buri, nerijetko i jedan od najtoplijih gradova na obali pa i u cijeloj zemlji. Reljefnim i klimatskim obilježjima prilagođen je i prirodni vegetacijski pokrov. Oskudna vegetacija posljedica je, osim prirodnih uvjeta, i ljudskog utjecaja - tradicionalnoga stočarstva, uzgoja koza i ovaca, te sječe šuma. Stoga podgorski krajolik ostavlja prevladavajući dojam surova kamenjara bez premca na kopnenom dijelu hrvatske obale. Sušnosti pridonosi i činjenica da na cijelom Podgorju nema znatnijih površinskih vodotoka. Jedine iznimke u tom pogledu jesu potoci u Velikoj Paklenici i Maloj Paklenici. S druge strane, za Podgorje je tipična česta pojava vrulja, podmorskih izvora na kojima izvire slatka voda što pritječe podzemnim putem iz planinskoga zaleđa.

Prema današnjoj upravnoj podjeli Podgorje se nalazi u sastavu dviju županija. Veći, sjeverni dio u sastavu je Ličko-senjske županije i to grada Senja i općine Karlobag. Južni dio u sastavu je Zadarske županije, odnosno pripadajuće joj općine Starigrad. Ako se Podgorje računa sve do Zrmanje, dakle uključujući i krajnji jugoistočni dio podvelebitskog područja kojime Podgorje prelazi u Bukovicu, onda je njime obuhvaćena i općina Jasenica, u sastavu koje se nalaze, primjerice, priobalna naselja odnosno dijelovi naselja Rovanjska i Maslenica. Iz praktičnih razloga preciznijeg omeđivanja, pravim "podgorskim" jedinicama mogu se ipak smatrati samo grad Senj i općine Karlobag i Starigrad. Površina tih triju jedinica iznosi 1111 četvornih kilometara, a prema popisu stanovnika 2011. imale su zajedno manje od 10000 stanovnika (Senj 7182 st., Karlobag 917 st., Starigrad 1876 st.). Od ukupnog broja stanovnika općine Senj treba još oduzeti i broj stanovnika naselja koja nipošto nisu podgorska. To su naselja Vratnik, Melnice, Vrzići Crni Kal i Krasno s ukupno 672 stanovnika. Bez tih naselja, zbroj stanovnika triju jedinica iznosi 9303, a s obzirom na površinu od približno 1000 četvornih kilometara (također bez spomenutih naselja), gustoća stanovnika Podgorja 2011. godine bila je manje od 10 stanovnika po četvornom kilometru.

${ }^{13}$ V. ROGIĆ, 1957, 80. 
Već i po tom pokazatelju, riječ je o najrjeđe naseljenom dijelu Hrvatske, čemu dodatno pridonosi činjenica da je više od polovice ukupnog broja stanovnika koncentrirano u samome Senju. Stoga, ako se Senj ne smatra sastavnim dijelom Podgorja, gustoća naseljenosti manja je od 5 stanovnika po četvornome kilometru i može se zaključiti da ima anekumenska obilježja.

Najveće naselje je Senj, nekad glavna sjevernojadranska luka, koja gubi prometno značenje nakon izgradnje prve jadranske željezničke pruge do Rijeke 1873., ali zadržava važnost lokalnoga središta. Senj ima dugačak kontunitet postojanja koji seže u antičko vrijeme, kada je na mjestu Senja bila rimska Senia. Dugotrajno postojanje gradskog naselja rezultat je smještaja Senja u podnožju planinskog prijevoja Vratnik, preko kojega se održavala veza sa zaleđem. I ostala značajnija naselja nastala su na mjestu antičkih naselja: Sv. Juraj na mjestu Lopsice, Jablanac na mjestu Ortopule, Karlobag na mjestu Vegiuma, Starigrad-Paklenica na mjestu Argyruntuma. S iznimkom Starigrada, i ta se naselja nalaze u podnožju velebitskih prijevoja, Oltara, Velikog Alana i Oštarijskih vrata pa se može govoriti o istome obrascu njihova nastanka i opstanka kao luka na terminalnim točkama prometno-trgovačkih veza koje su povezivale morsku obalu i ličko zaleđe. Slabo naseljeno Podgorje samo po sebi zacijelo nije moglo omogućiti razvoj nijednog znatnijeg gradskog središta na tom dijelu obale. Podgorska uzmorska mjesta svojim se izgledom razlikuju od uobičajenoga izgleda naših primorskih gradića, dok ruralna naselja imaju fizionomiju sela dinarskoga planinskog pojasa.

Zbog siromašne prirodne osnove tradicionalno se podgorsko gospodarstvo zasnivalo na ekstenzivnom stočarstvu te obradi minijaturnih krških udubina u kojima se tlo branilo kamenim suhozidima. Budući da su obradive površine bile rijetke i oskudne, stočarstvo je bilo važnije od poljodjelstva. Posebice je ojačalo od druge polovice 17. stoljeća, otkad vojnokrajiška uprava potiče naseljavanje Podgorja. Uza sitno stočarstvo, uzgoj koza i ovaca, stanovništvo je nastojalo osigurati i dodatna sredstva za preživljavanje. Dopunske izvore prihoda crpilo je iz korištenja velebitskih šuma i prijevozu drva, a na izvozu drva dopremanog s Velebita živjele su i malobrojne podgorske luke. Jedina ribarska luka bila je Lukovo. U novije vrijeme dodatnu zaradu stanovništvu omogućila je i izgradnja Jadranske magistrale, koja se na podgorskom dijelu odvijala u razdoblju 195559. Nakon njezine izgradnje stvorile su se pretpostavke za razvoj turizma, međutim i dalje u mnogo skromnijem opsegu nego na drugim dijelovima hrvatskoga primorja. Turizam jest bio čimbenik modernizacije, no Podgorje je uvelike ostalo, kada je o turizmu riječ, tranzitno područje. Jadranska magistrala jest povezala Podgorje uzdužno kao i s drugim dijelovima primorja, a njome su od početka 60 -ih počeli masovnije dolaziti i turisti, no njihova krajnja odredišta 


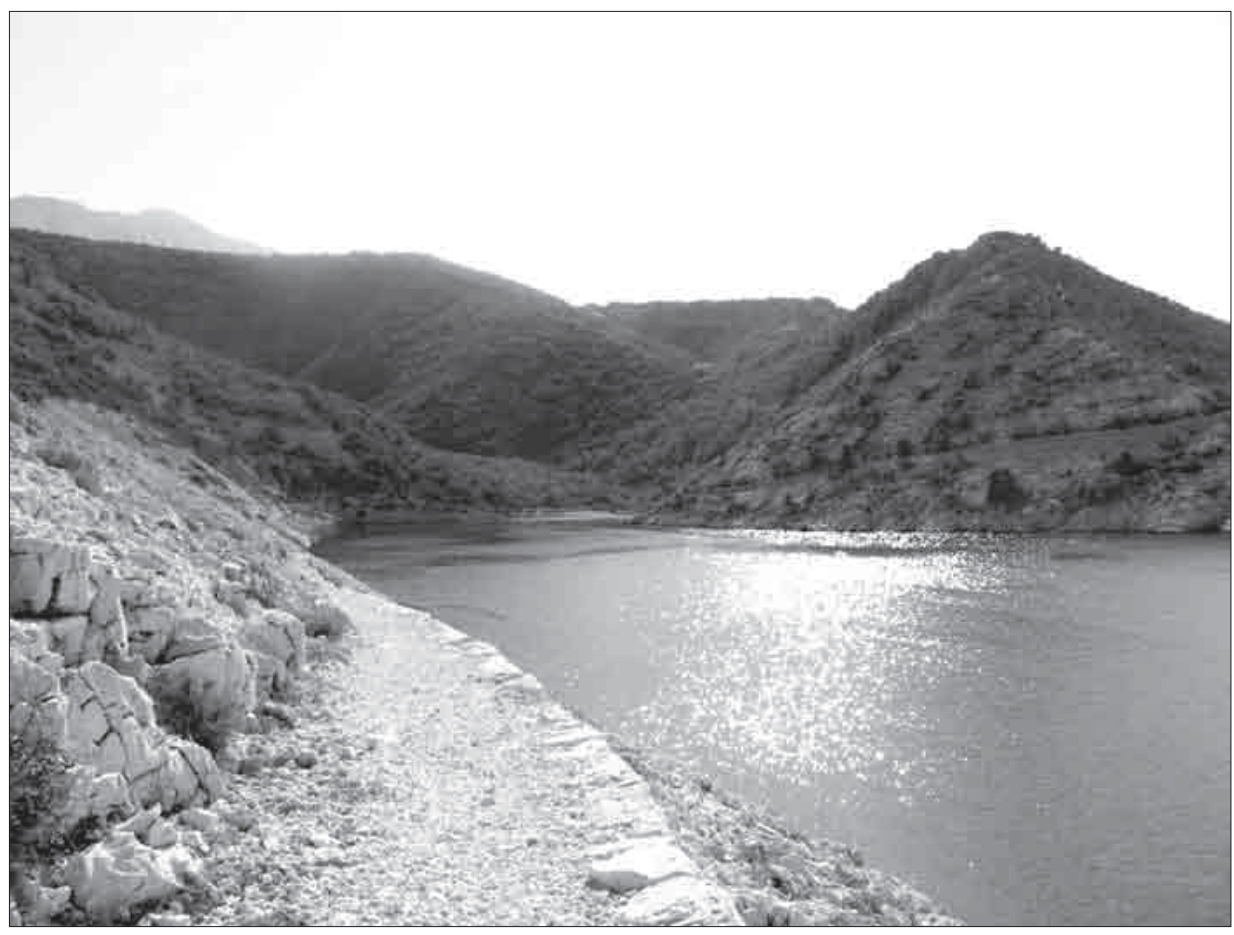

S1. 2. Uvala Grbačka kraj Starigrada Senjskog i stara pješačka staza koja povezuje podgorska uzmorska naselja - podgorski lungomare, foto: M. Klemenčić, 2014.

samo iznimno bila su u samome Podgorju. Tome pridonose i trajektne luke koje s podgorskog dijela obale vode na otoke. Prva trajektna linija iz Jablanca za Rab, otvorena 1963, jedna je od najstarijih na našoj obali. Potom su otvorene i druge, Senj-Baška-Lopar i Karlobag-Pag, a danas prometuju dvije, iz Prizne za otok Pag i iz Stinice (umjesto iz Jablanca) za otok Rab, no one samo potvrđuju tranzitnu ulogu Podgorja. Na cijelom podgorskom priobalnom pojasu nema ni jedne turističke "destinacije" poznate u nacionalnim razmjerima. Teško je sjetiti se čak i neke reklame koja poziva turiste da svoj odmor provedu u Podgorju. ${ }^{14}$ Najpovoljnije uvjete za razvoj turizma ima Starigrad-Paklenica, zbog blizine dinamičnih sjevernodalmatinskih turističkih središta te, posebice, kao ishodišno naselje posjetitelja nacionalnoga parka Paklenice. Tamo se nalazi i danas jedini

${ }^{14}$ Autor priloga u više je navrata u 70-im, 80-im, 90-im i 2000-im godina dulje ili kraće vrijeme proveo u Senju i u Podgorju kao i na Velebitu, stoga se tekst djelomice zasniva i na spoznajama stečenima za opetovanih posjeta i boravaka na terenu. 
veći hotel na cijelom podgorskom dijelu obale. Drugi velebitski nacionalni park, slabije posjećeni i teže pristupačni Sjeverni Velebit, nema isto takvo značenje za podgorska naselja u svom podnožju. U turističkom pogledu Podgorje je najmanje posjećeni dio hrvatske obale, ono je i dalje odredište samo rijetkih pojedinaca koji prednost daju očuvanoj prirodi, tišini i miru, dok se masovni turizam događa negdje drugdje.

Na temelju ovog kratkog ogleda, koji nema drugih ambicija osim da posluži kao uvod u šire elaboracije raznovrsnih specijalističkih tema, može se zaključiti da se Podgorje po svojim zemljopisnim obilježjima, ponajprije krajobraznim, demografskim i gospodarskim, jasno razlikuje od primorskih krajeva smještenih sjevernije i južnije. Od zaleđa, pak, jasno je odvojeno visokom planinskom barijerom Velebita, dominantnim reljefnim oblikom širega područja. Točan prostorni obuhvat Podgorja u literaturi nije jednoznačno određen. O tome bi valjalo poduzeti posebno ciljano istraživanje, s obvezatnom anketom, koje bi dalo odgovor na pitanje je li Senj sastavni dio Podgorja ili samo najbliži grad kao i odgovor na pitanje je li južna međa Podgorja povijesna granica Primorja i Dalmacije ili ju treba smjestiti južnije, tako da obuhvati i dio dalmatinske obale oko Starigrada pa i sve do rijeke Zrmanje. Kada je o razvojnim perspektivama riječ, u demografski opustjelome Podgorju one nisu ni raznovrsne pa ni obećavajuće. Ipak, kao krajobrazno poseban, izgradnjom i turizmom nezasićen dio obale, u uvjetima dobrog i uravnoteženog razvojnog planiranja priobalja, kao i cjelokupnog nacionalnog prostora, zacijelo i Podgorje može pronaći svoje mjesto kao prostor pogodan za njegovanje drugačijeg turizma.

\section{Literatura}

Geografija SR Hrvatske 5, Sjeverno Hrvatsko primorje, Zagreb, 1975.

Dragutin HIRC, Okolo Velebita, u: Prirodni zemljopis Hrvatske, knjiga prva: Lice naše domovine, Zagreb, 1905.

Hrvatska enciklopedija, 11, Zagreb, 2009.

Damir MAGAŠ, Geografija Hrvatske, Zadar, 2013.

Lena MIROŠEVIĆ - Branimir VUKOSAV, Prostorni identiteti otoka Paga i Južnoga podvelebitskog primorja. GeoAdria, 15/1, 2010, 81-108.

Opća i nacionalna enciklopedija u 20 knjiga, Zagreb, 2007.

Josip POLJAK, Planinarski vodič po Velebitu, Zagreb, 1929.

Željko POLJAK i suradnici, Velebit, Zagreb, 1969.

Veljko ROGIĆ, Razlike pejzaža velebitskih padina, Geografski glasnik, XVIII, Zagreb, 1956, 15-32. 
Veljko ROGIĆ, Velebitska primorska padina. Prilog poznavanju evolucije krškog pejzaža, Geografski glasnik, XIX, Zagreb, 1957, 61-102.

Veljko ROGIĆ, Velebitska primorska padina. Prilog poznavanju evolucije krškog pejzaža (nastavak), Geografski glasnik, XX, Zagreb, 1958, 53-115.

Veljko ROGIĆ, Regionalizacija Jugoslavije, Geografski glasnik, XXXV, Zagreb, 1973, 13-28.

Veliki atlas Hrvatske, Zagreb, 2002.

\section{THE UNDERSTANDING AND BASIC GEOGRAPHICAL FEATURES OF PODGORJE}

Summary

In the paper the spatial coverage and the understanding of Podgorje as a specific Croatian region are discussed. By its many features Podgorje is an atypical part of the Croatian coastal belt, with specific identity features. The name itself already points to the mountain ("podgorje" "foothills"), and not to the sea as a starting point. There are various points of view in the literature about the correct definition of the area that Podgorje encompasses. The Podgorje coastal places with their appearance differ from the regular appearance of our little littoral towns, whilst the rural settlements have the physiognomy of a village of the Dinaric mountain belt. In addition, the main features of the coverage of the region's population are presented. Without the town of Senj, and even with it, this is a sparsely populated part of Croatia. From the view of transport, the 1950 s were crucial years of the construction of the main Adriatic highway - the magistrale, which longitudinally connected the whole of Podgorje.

Keywords: Podgorje, geographic features 